\title{
Application of Analytic Hierarchy Process (AHP) to Develop the Weighting of Key Performance Indicators on Gas Engine Power Plants
}

\author{
Dedi Emawan \\ Master of Mechanical Engineering \\ Swiss German University \\ Alam Sutera, Indonesia \\ dediemawan@gmail.com
}

\author{
Aditya Tirta Pratama \\ Department of Industrial Engineering \\ Swiss German University \\ Alam Sutera, Indonesia \\ aditya.pratama@sgu.ac.id
}

\author{
Henry Nasution \\ Master of Mechanical Engineering \\ Swiss German University \\ Alam Sutera, Indonesia \\ henry.nasution@sgu.ac.id
}

\begin{abstract}
Power plants as electricity producers need to be maintained using monitoring performance and continuous improvements. Company management of power plant is difficult to make a decision for the continuous improvement, requires Performance Measurement Tools (PMT) to determine the performance of a gas engine power plant. PMT developed using Key Performance Indicator (KPI) that was defined through Forum Group Discussion (FGD) with different field of expertise in company and based on references and the weighting of KPI criterion that was developed by Analytic Hierarchy Process (AHP). This study has developed the weight of KPI that the weight of each criterion which will be used as a reference is Rank 1 - Power Output (MW) - PO (70.81\%), Rank 2 - Heat Rate (Btu/kWh) - HR (14.91\%), Operating Ratio (\%) - OR (8.06\%) and Rank 4-Capacity Factor (\%) - CF (6.22\%).
\end{abstract}

Keywords-analytic hierarchy process, power plants, gas engine generator, key performance indicators, performance measurement tools.

\section{INTRODUCTION}

Electricity has become an essential requirement of every modern human being. Power plants as electricity producers face the electricity demand that continues to increase over time. Power plants are as electricity producers. Generally, there are five types of power plants in Indonesia based on energy sources: Hydro Power Plant, Steam (Coal) Fired Power Plant, Gas-Fired Power plant, Diesel Fired Power Plant, and other renewable resources such as solar, wind, geothermal, and biomass [1].

Development of Fuel Mix for Power Generation in 2017 shows that the use of Coal as a Fuel is in the first rank $(57.22 \%)$, the second rank is Fuel Gas $(24.82 \%)$, followed by the third rank by Hydro (7.06\%), the fourth rank Oil $(5.81 \%)$, and finally, the fifth rank is Geothermal + New and Renewable Energy (5.09\%) [2].

Fuel gas $(24.82 \%)$ is the second level for power generation in Indonesia. There are two gas-fired power plants that using fuel gas (Gas Turbine Power Plant and Gas Engine Power Plant). This study focuses on Gas Engine Power Plant. Gas Engine Power Plant is the power plant that using Gas Engine Generator (GEG) as a prime mover to generate electricity. Company management of Gas Engine Power Plant has an agreement with National Electricity Provider or customer. The agreement is a contract signed by both parties. In the contract, the customer can give a penalty to the company if the actual value does not match the value written in the contract. The actual values are the Key Performance Indicator (KPI) values in the gas engine power plants. KPIs were defined through Forum Group Discussion (FGD) with different fields of expertise in the company and based on references. The results of FGD are the determination of KPI used to measure performance on gas engine power plants such as Power Output (MW), Heat Rate (Btu/kWh), Operating Ratio (\%), Capacity Factor (\%). This study is to measure the weighting of those KPIs using the Analytic Hierarchy Process (AHP).

\section{LITERATURE REVIEW}

This section provides an overview as a guideline and a strong background for the topic of this study.

\section{A. Power Plant}

A power plant is an industrial facility that generates electricity from primary energy. Most power plants use one or more generators. This generator converts mechanical energy from primary mover (rotating machine) into electrical energy in order to supply the electrical power to the electrical grid to fulfill the needs of electrical in the society [3]. A power plant is also referred to as a power station and sometimes a power generation station or plant.

The type of primary fuel or primary energy flow that provides a power plant its primary energy varies. The most common fuels are coal, natural gas, and uranium (nuclear power) [3].

\section{B. Gas Engine Generator}

The primary mover that will be discussed is the gas engine. A gas engine is an internal combustion engine that burns on gaseous fuel, such as natural gas, biogas, landfill gas, coal mine gas, and sewage gas. A gas engine is also called a gaseous-fuelled engine or natural gas engine, or 
spark-ignited engine. The company uses gas engine with the brand GE Jenbacher. GE Jenbacher are manufactured in Jenbach, Austria, with more than five decades of experience in gas engine manufacturing and has more than 10,000 generators installed worldwide so far [4]. A case study was taken in a company with quite a lot of gas-engine generator power plants.

\section{Performance Measurement Tools (PMT)}

Performance Measurement is the process of collecting, analyzing, and/or reporting information regarding the performance of an individual, group, organization, system, or component. [5].

For companies to increase competitiveness, a performance measurement system (PMS) is needed, which provides relevant information for efficiency and effective management of making measurable decisions [5]. PMS is dynamic in nature, integrated with measurement and evaluation of the efficiency and effectiveness of business operations which can be used as a basis for decision making to increase competitiveness in a company.

Companies need performance measurement because it is beneficial for achieving eight specific managerial purposes, namely: evaluate, control, budget, motivate, promote, celebrate, learn and improve. To achieve these goals, it is necessary: 1. Evaluate; 2 . Control; 3. Budget; 4. Motivate; 5. Promote; 6. Celebrate; 7. Learn; 8. Improve.

PMT in this study is to help company management of power plant to make a decision for continuous improvement and to determine the performance of a gas engine power plant.

\section{Key Performance Indicators (KPI)}

A performance indicator or key performance indicator is a type of performance measurement. KPI is a measuring tool that describes the effectiveness of a company in achieving its business goals. Companies use KPIs to measure the success of achieving their targets [5]. KPI is for monitoring and detecting low performance in power plant operation, investigating issues, and setting up maintenance plans in order to minimize the operational cost [6]. KPI has three categories: Technical, Commercial, Technical, and Operational Capabilities [7]. In this study, performance indicators that be used are only technical performance indicators in gas engine power plants only.

Technical Performance Indicators are KPI where the indicators used are only for the technical part. In this study, the technical performance indicators used are a combination of information from the available literature. [6] said that Technical Performance Indicators based on operational data consist of: 1. The Average Power (PAvg); 2. Installed Power Load Factor $(\mathrm{Ku})$; 3. Installed Power Load Duration (Ti); 4. Maximum Power Load Duration (Tmax); 5. Power Factor $(\operatorname{Cos} \theta)$; 6. Performance Index (PI).

Meanwhile, according to [7], Technical Performance Indicators consist of: 1. Capacity Factor; 2. Load Factor; 3. Operating Ratio.
According to [8], Technical Performance Indicator for a power plant with a low Heat Rate indicator will produce maximum efficiency for the power plant. The Heat Rate is the ratio of energy used to generate $1 \mathrm{kWh}$ of electricity.

KPI that used to measure performance on gas engine power plants refers to references from [6-8]: 1. The Average Power (PAvg); 2. Installed Power Load Factor $(\mathrm{Ku}) ; 3$.

Power Factor $(\operatorname{Cos} \theta)$; 4. Capacity Factor; 5. Operating Ratio; 6. The Heat Rate

\section{E. Analytic Hierarchy Program (AHP)}

The Analytic Hierarchy Process (AHP) was introduced by Thomas Saaty. The AHP is an effective tool for dealing with complex decision-making and may help the decisionmaker set priorities and make the best decision. By reducing complex decisions to a series of pairwise comparisons, and then synthesizing the results, the AHP helps to capture both subjective and objective aspects of a decision. In addition, the AHP incorporates a useful technique for checking the consistency of the decision maker's evaluations, thus reducing the bias in the decision-making process [9].

The hierarchy structure in AHP is divided into three levels. Level 0 is the goal of the analysis. Level 1 is factors or criteria that to relate the alternatives to reach the goal. The criteria are ordered from the highest priorities on the left to lower priorities to the right. Lastly is level 2 . This level is the alternative choices which is the group of options. The lines between levels indicate the relationship between goal, criteria, and alternatives [9].

The process of AHP that defined by Thomas Saaty as follows:

1. Model the problem as a hierarchy containing the decision goal, the alternatives for reaching it, and the criteria for evaluating the alternatives.

2. Establish priorities among the hierarchy elements by making a series of judgments based on pairwise comparisons of the elements. For example, when comparing potential purchases of commercial real estate, the investors might say they prefer location over price and price over timing.

3. Synthesize these judgments to yield a set of overall priorities for the hierarchy. This process would combine the investors' judgments about location, price, and timing for properties A, B, C, and D into overall priorities for each property.

4. Check the consistency of the judgments.

5. Come to a final decision based on the results of this process

To make comparisons, we need a scale of numbers that indicates how many times more important or dominant one element is over another element, with respect to the criterion or property, with respect to which they are compared. The priorities comparison is measured using Pairwise Comparisons. The comparison is the sequence from bottom to top, from choices to factors and factors to goal. 
TABLE I

FUNDAMENTAL SCALE FOR PAIRWISE COMPARISON [10]

\begin{tabular}{|c|c|c|}
\hline $\begin{array}{l}\text { Intensity of } \\
\text { Importance }\end{array}$ & Definition & Explanation \\
\hline 1 & $\begin{array}{c}\text { Equal } \\
\text { Importance }\end{array}$ & $\begin{array}{l}\text { Two elements contribute } \\
\text { equally to the objective }\end{array}$ \\
\hline 3 & $\begin{array}{l}\text { Moderate } \\
\text { Importance }\end{array}$ & $\begin{array}{l}\text { Experience and Judgement } \\
\text { moderately favour one } \\
\text { element over another }\end{array}$ \\
\hline 5 & $\begin{array}{c}\text { Strong } \\
\text { Importance }\end{array}$ & $\begin{array}{c}\text { Experience and Judgement } \\
\text { strongly favour one element } \\
\text { over another }\end{array}$ \\
\hline 7 & $\begin{array}{l}\text { Very Strong } \\
\text { Importance }\end{array}$ & $\begin{array}{l}\text { One element is favoured very } \\
\text { strongly over another; its } \\
\text { dominance is demonstrated in } \\
\text { practice }\end{array}$ \\
\hline 9 & $\begin{array}{c}\text { Extreme } \\
\text { Importance }\end{array}$ & $\begin{array}{l}\text { The evidence favouring one } \\
\text { element over another is of the } \\
\text { highest possible order of } \\
\text { affirmation }\end{array}$ \\
\hline
\end{tabular}

Intensities of 2, 4, 6 and 8 can be used to express intermediate values. Intensities of 1.1, 1.2, 1.3, etc. can be used for elements that very close in importance.

Table I shows the Fundamental Scale for Pairwise Comparisons, where this Scale is an assessment for the Intensity of Importance in Pairwise Comparison. The levels used are odd numbers $(1,3,5,7$, and 9$)$, while even numbers $(2,4,6$, and 8$)$ are used to express intermediate values.

The AHP generates a weight for each evaluation criterion according to the decision maker's pairwise comparisons of the criteria. The higher the weight, the more important the corresponding criterion. Next, for a fixed criterion, the AHP assigns a score to each option according to the decision maker's pairwise comparisons of the options based on that criterion. The higher the score, the better the performance of the option with respect to the considered criterion. Finally, the AHP combines the criteria weights and the options scores, thus determining a global score for each option, and a consequent ranking. The global score for a given option is a weighted sum of the scores it obtained with respect to all the criteria [11].

\section{METHODOLOGY}

This methodology uses the application of Analytic Hierarchy Process (AHP) to develop the weighting of KPI that was previously defined through FGD with expertise in the company.

AHP is a multi-criteria decision-making methodology to set priorities and make the best decision. It is an appropriate tool for developing the weighting of KPI, used for gas engine power plant where the presence of multiple inputs and outputs makes comparisons difficult. AHP compares the criteria of KPI.

The weighting is used to get Performance Score of each gas engine power plant. It is essential to get weighting from expertise in the company. Preparing AHP Structure and Pairwise Comparison Matrix is a reference to develop the questionnaire. This questionnaire will be asked to expertise in the company.

The reason for using AHP is because it provides a systematic approach for weighting performance criteria to provide a comprehensive performance measure. In AHP, the problem analysis is set to be in a hierarchy that consists of goal, criteria, and alternatives. Hierarchy indicates a relationship between elements of one level with those of the level immediately below. Fig. 1 shows the hierarchy. After the hierarchy has been constructed, the analysis will be conducted using pairwise comparisons that derive numerical scales of measurement. Then priorities are established that represent the weights of each alternative. The higher the weight refers to the higher KPI.

At level 0, the intended goal is the KPI in the gas engine power plant. For the Level 1 criteria, the weighting will be sought viz Power Output $(\mathrm{KW})$, Heat Rate $(\mathrm{Btu} / \mathrm{kWh})$, Operating Ratio (\%), and Capacity Factor (\%). Meanwhile, Level 2 Alternatives uses the data from Power Plant A, Power Plant B, and Power Plant C.

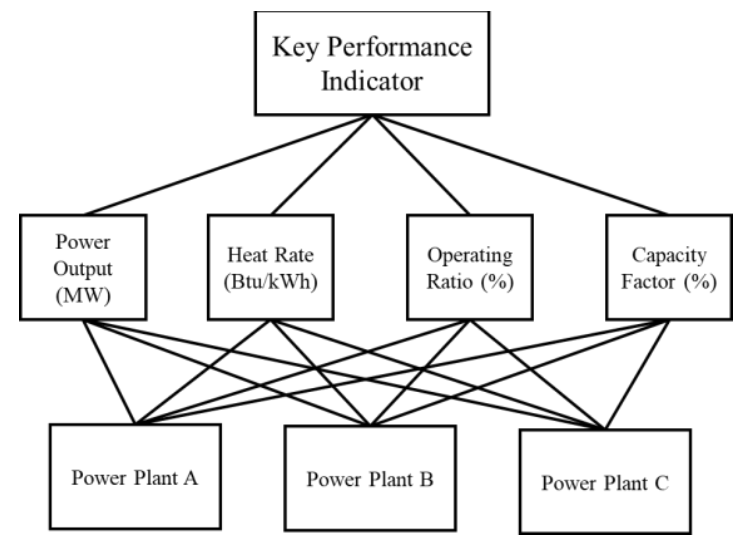

Fig. 1. AHP structure

The comparisons were made for each criterion of Performance Indicators (Power Output $(\mathrm{kW})$, Heat Rate (Btu/kWh), Operating Ratio (\%), Capacity Factor (\%). A Pairwise Comparison in expert judgment is the process of comparing the relative importance with respect to another element in the level above. Data collected from experts or decision-makers corresponding to the hierarchy structure. The pairwise comparisons of criteria generated were organized into a square matrix. After the matrix is set, the next process is Synthesization. Synthesization is a process of calculating the priority of each criterion in terms of its contribution to the overall goal of achieving KM performance. The steps of Synthesization are:

1. Calculate the average in each column of the pairwise comparison matrix. 
Calculations with AHP are always guided by the experience of decision-makers, and AHP can be considered as a tool capable of translating evaluations into multicriteria rankings. The average is calculated based on numerical values arranged into a square matrix A shown in Table $2 \mathrm{a}_{\mathrm{jk}}$ represents the importance of the matrix A of the $\mathrm{j}^{\text {th }}$ creation relative to the $\mathrm{k}^{\text {th }}$ criterion. If two criteria have the same importance, then entry $a_{j k}$ is 1 . If $a_{j k}$ is greater than 1 , then the $\mathrm{j}^{\text {th }}$ criterion is more important than the $\mathrm{k}^{\text {th }}$ criterion, whereas if $\mathrm{a}_{\mathrm{jk}}$ is less than 1 , then the $\mathrm{j}^{\mathrm{th}}$ criterion is less important than the $\mathrm{k}^{\text {th }}$ criterion. Criteria that have different interests can be explained in Equation 1:

$$
a_{j k}=\frac{1}{a_{j k}} ; \text { For } \mathrm{j} \neq \mathrm{k}
$$

The matrix of this study is as can be seen in Table 2 .

TABLE II

RESEARCH PAIRWISE COMPARISONS

\begin{tabular}{ccccc}
\hline CRITERIA & $\begin{array}{c}\text { Power } \\
\text { Output }\end{array}$ & $\begin{array}{c}\text { Heat } \\
\text { Rate }\end{array}$ & $\begin{array}{c}\text { Operating } \\
\text { Ratio }\end{array}$ & $\begin{array}{c}\text { Capacity } \\
\text { Factor }\end{array}$ \\
\hline Power Output & 1 & & & \\
Heat Rate & & 1 & & \\
Operating Ratio & & & 1 & \\
Capacity Factor & & & & 1 \\
\hline
\end{tabular}

2. Divide each element by its column total (gives normalized pairwise comparison matrix).

The comparisons are processed mathematically, and priorities are derived for each node. After evaluation based on the weight of each factor is built, sum normalization is needed since a smaller weight value is preferable to higher weight. The normalization derives by making the sum of the entries on each column is equal to one. 2 [10]:

The formula of the normalized score shows in Equation

$$
\text { Normalized score }=\frac{A_{j k}}{\sum_{l=1}^{m} A_{l k}}
$$

3. Calculate the average of elements in each row (estimate relative priorities of elements being compared).

This step finds the largest weight of the maximum Eigen-value. The principal Eigen-value is obtained from the summation of products between each element of the Eigenvector and the sum of columns of the reciprocal matrix. Under the condition, the total weight is equal to one. The formula of Eigen-value of $\mathrm{n}$ size of comparison matrix is in Equation 3 about the weight of criteria:

$$
W_{j}=\frac{\sum_{l=1}^{m} A_{j k}}{n}
$$

The maximum eigen-vector is calculated according to the Equation 4:

$$
\lambda \max =\frac{1}{n} \sum_{i=j}^{n} \frac{(A w)_{j}}{w_{j}}
$$

The calculation of eigen-vector and eigen-value gives good results when there is high consistency in the pairwise comparisons. The result obtained is an approximation, but the more precise the result than the more consistent the evaluations [10].

The next step is the Comparison Consistency evaluation. Individual elements are evaluated, and the consistency of the evaluation is checked. The evaluation works by comparing all pairs of elements at a given level from each element's point of view located a level higher in the previously constructed hierarchical structure.

A slight inconsistency might be arising if the decisionmaker evaluates that one criterion is also slightly more important than the other criterion. Then the evaluation of decision-maker should be by gave a measure of consistency, called Consistency Index as deviation or degree of consistency using the Equation 5:

$$
C I=\frac{\lambda \max -n}{n-1}
$$

Random Index (RI) is used index by comparing it with the appropriate one. Random Index (RI) is the average consistency index of 100 randomly generated (inconsistent) pairwise comparisons matrices.

The values of RI for small problems where the size of the comparison matrix is less than ten are shown in Table 3.

TABLE III

VALUE OF RANDOM INDEX (RI) FOR SMALL PROBLEM

\begin{tabular}{cccccccccc}
\hline $\mathrm{n}$ & 2 & 3 & 4 & 5 & 6 & 7 & 8 & 9 & 10 \\
\hline $\mathrm{RI}$ & 0 & 0.58 & 0.90 & 1.12 & 1.24 & 1.32 & 1.41 & 1.45 & 1.51 \\
\hline
\end{tabular}

Consistency Ratio is a comparison between the Consistency Index and Random Consistency Index, which is used to find whether small values of inconsistency may be tolerated or not. The formula of Consistency Ratio (CR) shows in Equation 6:

$$
C R=\frac{C I}{R I}
$$

If the Consistency Ratio's value is smaller or equal to $10 \%$, the consistency is acceptable. If the Consistency Ratio is greater than $10 \%$, we need to revise the subjective judgment.

The result of the comparisons is a set of matrices that, after normalization and examination of consistency, form the basis for the system's final evaluation [12].

Aggregate the relative weights of criteria are calculated. The weights of criteria are aggregated to determine a compromise weight for group decision-making that minimizes conflict among the different individual preferences. [13] uses an aggregation procedure based on geometric means to calculate the global scores for a group of participants. Suppose different individuals rank different subsets of the criteria. In that case, the recommended method is the aggregate weights proposed by [13], which converts individual ranks into individual weights and then calculates aggregate weights as averages of individual 
weights [13]. The equation, where $m$ is the number of individuals, is in Equation 7:

$$
W_{j}=\sqrt[m]{W_{1, j} \times W_{2, j} \times \ldots \times W_{m, j}} ; j=1, \cdots, \mathrm{n}
$$

Then the results of the factor analysis have served as the weight for Key Performance Indicators. The weight is decided from all variables that are accepted based on factor analysis. The weight is calculated from the average of each value from the result of the questionnaire survey distributed to company expertise. The Key Performance Indicators weight was calculated by dividing the total average value by the average value. The calculation is using Microsoft Excel as a tool.

\section{FINDINGS AND DISCUSSIONS}

The company uses KPI as an indicator to calculate its performance that reflects the gas engine power plant's performance. The KPIs that are used to measure performance on gas engine power plants as follows: 1 . Power Output (MW) - PO is the total power output average produced by the power plant; 2 . Heat Rate $(\mathrm{Btu} / \mathrm{kWh})-\mathrm{HR}$ is the amount of energy used by the power plant to generate one-kilowatt hour $(\mathrm{kWh})$. Energy is in British Thermal Units (BTU); 3. Operating Ratio (\%) - OR is the ratio of gas engine operating to total gas engine installed in power plant; 4. Capacity Factor $(\%)-\mathrm{CF}$ is a ratio of actual generation of power to maximum capacity to generate. This indicator measures the percentage of installed capacity that was utilized.

The weighting value of KPI is the result of AHP calculations from the answers of the expertise in the company. The questionnaire method is used to get answers from the expertise. This questionnaire is designed to obtain weighting of KPI. This questionnaire will be distributed to the expertise in the company, especially the manager who leads the department related to the operation of the gas engine power plant. They are Operation General Manager, Technology \& Business Support General Manager, Active Contract General Manager, Asset Management System Manager.

This questionnaire asks about the information from the respondents, namely the expertise in the company, there are: name, gender, position, how long have you been working for the company, department and the relative importance of "Chair Criteria" with respect to "Selecting Chairs" with the intensity of importance level. This questionnaire design, then made with Google Forms so that it is easy to distribute and receive responses from expertise.

In Table 4 shows that there is 4 expertise (responder) who gave answers to the questionnaire given. The intensity of importance for each KPI has also been given.

The next step is to calculate the Consistency Index (CI). The equation used is to follow equation 5, namely CI. After getting CI for each expertise, calculate the Consistency Ratio (CR) using equation 6, namely CR. RI is the Random CI. The RI value can be seen in Table V. In this calculation the number of criteria $(n)$ is 4 , then the RI value is 0.90 . If the $\mathrm{CR}$ value is less than or equal to $10 \%$ from the $\mathrm{CR}$ calculation result, the consistency is ACCEPTABLE. If the $\mathrm{CR}$ is greater than $10 \%$, we need to revise the subjective judgment. Table 5 shows the CR calculation.

TABLE IV

RESPONDENTS OF QUESTIONNAIRE

\begin{tabular}{|c|c|c|c|c|}
\hline NO. & 1 & 2 & 3 & 4 \\
\hline Position & GM & Manager & GM & GM \\
\hline $\begin{array}{l}\text { How long have you } \\
\text { been working for } \\
\text { company? }\end{array}$ & $\begin{array}{l}11-15 \\
\text { years }\end{array}$ & $\begin{array}{l}5-10 \\
\text { years }\end{array}$ & $\begin{array}{l}5-10 \\
\text { years }\end{array}$ & $\begin{array}{l}5-10 \\
\text { years }\end{array}$ \\
\hline $\begin{array}{l}\text { Please choose your } \\
\text { department in } \\
\text { company? }\end{array}$ & $\begin{array}{l}\text { Active } \\
\text { Contract } \\
\text { Manage } \\
\text { ment }\end{array}$ & $\begin{array}{l}\text { Technolo } \\
\text { gy and } \\
\text { Business } \\
\text { Support } \\
\end{array}$ & $\begin{array}{l}\text { Operati } \\
\text { on }\end{array}$ & $\begin{array}{c}\text { Technol } \\
\text { ogy and } \\
\text { Business } \\
\text { Support } \\
\end{array}$ \\
\hline $\begin{array}{l}\text { 1. What is the relative } \\
\text { importance of "Power } \\
\text { Output (MW)" with } \\
\text { respect to "Heat Rate } \\
\text { (Btu/kWh)"? }\end{array}$ & $\begin{array}{l}\text { Power } \\
\text { Output } \\
\text { (MW) }\end{array}$ & $\begin{array}{l}\text { Power } \\
\text { Output } \\
\text { (MW) }\end{array}$ & $\begin{array}{l}\text { Power } \\
\text { Output } \\
\text { (MW) }\end{array}$ & $\begin{array}{l}\text { Power } \\
\text { Output } \\
\text { (MW) }\end{array}$ \\
\hline $\begin{array}{l}\text { Power Output (MW) - } \\
\text { Heat Rate (Btu/kWh) }\end{array}$ & 9 & 9 & 7 & 9 \\
\hline $\begin{array}{l}\text { 2. What is the relative } \\
\text { importance of "Power } \\
\text { Output (MW)" with } \\
\text { respect to "Operating } \\
\text { Ratio }(\%) \text { "? }\end{array}$ & $\begin{array}{l}\text { Power } \\
\text { Output } \\
\text { (MW) }\end{array}$ & $\begin{array}{l}\text { Power } \\
\text { Output } \\
\text { (MW) }\end{array}$ & $\begin{array}{l}\text { Power } \\
\text { Output } \\
\text { (MW) }\end{array}$ & $\begin{array}{l}\text { Power } \\
\text { Output } \\
\text { (MW) }\end{array}$ \\
\hline $\begin{array}{c}\text { Power Output (MW) - } \\
\text { Operating Ratio (\%) }\end{array}$ & 9 & 9 & 7 & 9 \\
\hline $\begin{array}{l}\text { 3. What is the relative } \\
\text { importance of "Power } \\
\text { Output (MW)" with } \\
\text { respect to "Capacity } \\
\text { Factor }(\%) " \text { ? }\end{array}$ & $\begin{array}{l}\text { Power } \\
\text { Output } \\
\text { (MW) }\end{array}$ & $\begin{array}{l}\text { Power } \\
\text { Output } \\
\text { (MW) }\end{array}$ & $\begin{array}{l}\text { Power } \\
\text { Output } \\
\text { (MW) }\end{array}$ & $\begin{array}{l}\text { Power } \\
\text { Output } \\
\text { (MW) }\end{array}$ \\
\hline $\begin{array}{c}\text { Power Output (MW) - } \\
\text { Capacity Factor (\%) }\end{array}$ & 9 & 9 & 7 & 9 \\
\hline $\begin{array}{l}\text { 4. What is the relative } \\
\text { importance of "Heat } \\
\text { Rate (Btu/kWh)" with } \\
\text { respect to "Operating } \\
\text { Ratio (\%)"? }\end{array}$ & $\begin{array}{c}\text { Heat } \\
\text { Rate } \\
(\mathrm{Btu} / \mathrm{kW} \\
\mathrm{h})\end{array}$ & $\begin{array}{l}\text { Heat Rate } \\
(\mathrm{Btu} / \mathrm{kWh} \\
\text { ) }\end{array}$ & $\begin{array}{l}\text { Heat } \\
\text { Rate } \\
(\mathrm{Btu} / \mathrm{k} \\
\text { Wh) }\end{array}$ & $\begin{array}{c}\text { Heat } \\
\text { Rate } \\
(\mathrm{Btu} / \mathrm{kW} \\
\text { h) }\end{array}$ \\
\hline $\begin{array}{c}\text { Heat Rate }(\text { Btu/kWh) - } \\
\text { Operating Ratio }(\%)\end{array}$ & 3 & 3 & 3 & 3 \\
\hline $\begin{array}{l}\text { 5. What is the relative } \\
\text { importance of "Heat } \\
\text { Rate (Btu/kWh)" with } \\
\text { respect to "Capacity } \\
\text { Factor }(\%) " \text { ? }\end{array}$ & $\begin{array}{c}\text { Heat } \\
\text { Rate } \\
(\mathrm{Btu} / \mathrm{kW} \\
\text { h) }\end{array}$ & $\begin{array}{c}\text { Heat Rate } \\
(\mathrm{Btu} / \mathrm{kWh} \\
)\end{array}$ & $\begin{array}{l}\text { Heat } \\
\text { Rate } \\
(\mathrm{Btu} / \mathrm{k} \\
\text { Wh) }\end{array}$ & $\begin{array}{c}\text { Heat } \\
\text { Rate } \\
(\mathrm{Btu} / \mathrm{kW} \\
\text { h) }\end{array}$ \\
\hline $\begin{array}{c}\text { Heat Rate }(\text { Btu/kWh) - } \\
\text { Capacity Factor }(\%)\end{array}$ & 3 & 3 & 2 & 2 \\
\hline $\begin{array}{l}\text { 6. What is the relative } \\
\text { importance of } \\
\text { "Operating Ratio (\%)" } \\
\text { with respect to } \\
\text { "Capacity Factor } \\
(\%) " ?\end{array}$ & $\begin{array}{l}\text { Operatin } \\
\text { g Ratio } \\
(\%)\end{array}$ & $\begin{array}{l}\text { Operating } \\
\text { Ratio }(\%)\end{array}$ & $\begin{array}{c}\text { Operati } \\
\text { ng } \\
\text { Ratio } \\
(\%)\end{array}$ & $\begin{array}{c}\text { Operatin } \\
\text { g Ratio } \\
(\%)\end{array}$ \\
\hline $\begin{array}{c}\text { Operating Ratio (\%) - } \\
\text { Capacity Factor (\%) }\end{array}$ & 1 & 2 & 2 & 2 \\
\hline
\end{tabular}

The next step is to calculate the weight for each criterion using the aggregate of the relative weights of the criteria. Aggregation procedure based on Geometric Means using Equation 7, which is the square root of 4 (number of criteria) from the multiplication of each weighting of expertise. After obtaining the geometric means value, then calculate the Normalized Geometric Means by dividing each criterion's geometric mean value by the total number of Geometric 
Mean. Table 6 shows the results of calculating the aggregating weight of the criteria.

TABLE V

CONSISTENCY RATIO CALCULATION RESULT

\begin{tabular}{|c|c|c|c|c|c|c|}
\hline $\begin{array}{l}\mathrm{N} \\
\mathrm{O}\end{array}$ & Responder & $\lambda \max$ & $\begin{array}{l}\text { Consisten } \\
\text { cy Index } \\
\text { (CI) }\end{array}$ & $\begin{array}{l}\text { Rand } \\
\text { om } \\
\text { Index } \\
\text { (RI) }\end{array}$ & $\begin{array}{l}\text { Consi } \\
\text { stency } \\
\text { Ratio } \\
(\mathrm{CR}) \\
\end{array}$ & $\begin{array}{c}\mathrm{CR}< \\
0.10\end{array}$ \\
\hline 1 & Expertise 1 & 4.16 & 0.053 & 0.900 & 0.059 & $\begin{array}{c}\text { Accep } \\
\text { table }\end{array}$ \\
\hline 2 & Expertise 2 & 4.22 & 0.074 & 0.900 & 0.083 & $\begin{array}{c}\text { Accep } \\
\text { table }\end{array}$ \\
\hline 3 & Expertise 3 & 4.22 & 0.074 & 0.900 & 0.083 & $\begin{array}{c}\text { Accep } \\
\text { table }\end{array}$ \\
\hline 4 & Expertise 4 & 4.22 & 0.075 & 0.900 & 0.083 & $\begin{array}{c}\text { Accep } \\
\text { table }\end{array}$ \\
\hline
\end{tabular}

TABLE VI

AgGREgATING WEIGHTS From CRITERIA

\begin{tabular}{|c|c|c|c|c|c|c|}
\hline CRITERIA & E1 & E2 & E3 & E4 & $\begin{array}{c}\text { Geomet } \\
\text { ric } \\
\text { Mean }\end{array}$ & $\begin{array}{c}\text { Normalized } \\
\text { Geometric } \\
\text { Mean }\end{array}$ \\
\hline $\mathrm{PO}$ & $71.99 \%$ & $71.51 \%$ & $67.11 \%$ & $72.26 \%$ & $70.68 \%$ & $70.81 \%$ \\
\hline HR & $15.14 \%$ & $14.98 \%$ & $16.02 \%$ & $13.52 \%$ & $14.89 \%$ & $14.91 \%$ \\
\hline OR & $6.44 \%$ & $8.05 \%$ & $9.78 \%$ & $8.28 \%$ & $8.05 \%$ & $8.06 \%$ \\
\hline $\mathrm{CF}$ & $6.44 \%$ & $5.46 \%$ & $7.09 \%$ & $5.95 \%$ & $6.20 \%$ & $6.22 \%$ \\
\hline & & & & Sum & $99.82 \%$ & $100.00 \%$ \\
\hline
\end{tabular}

And the ranking can be seen in Table 7.

TABLE VII

WEIGHTS EACH CRITERIA

\begin{tabular}{|c|c|c|c|c|}
\hline No & Criteria & Code & Weights & Rank \\
\hline 1 & $\begin{array}{l}\text { Power } \\
\text { Output } \\
\text { (MW) }\end{array}$ & $\mathrm{PO}$ & $70.81 \%$ & 1 \\
\hline 2 & $\begin{array}{l}\text { Heat Rate } \\
(\text { Btu/kWh) }\end{array}$ & HR & $14.91 \%$ & 2 \\
\hline 3 & $\begin{array}{l}\text { Operating } \\
\text { Ratio }(\%)\end{array}$ & OR & $8.06 \%$ & 3 \\
\hline 4 & $\begin{array}{c}\text { Capacity } \\
\text { Factor }(\%)\end{array}$ & $\mathrm{CF}$ & $6.22 \%$ & 4 \\
\hline & & & TOTAL & $100.00 \%$ \\
\hline
\end{tabular}

\section{CONCLUSION}

Electricity has become a basic requirement of every modern human being. The demand for electricity continues to increase over time. Power plants as electricity producers need to be maintained using monitoring performance, carrying out maintenance on time and continuously improving.

For this reason, performance indicators are needed to define and can help determine the performance of a power plant through performance measurement. Power plant company is greatly helped in making decisions for continuous improvement with Performance Measurement.

This study has measured the weight of KPI that the weight of each criterion which will be used as a reference is Rank 1 - Power Output (MW) - PO (70.81\%), Rank 2 Heat Rate (Btu/kWh) - HR (14.91\%), Operating Ratio (\%) - OR (8.06\%) and Rank 4 - Capacity Factor (\%) - CF $(6.22 \%)$.

\section{REFERENCES}

[1] Deloitte Indonesia, 35,000 MW: A Light for the Nation, pp.1-50, 2016.

https://www2.deloitte.com/content/dam/Deloitte/id/Documents/fin ance/id-fas-35000mw-a-light-for-the-nation-noexp.pdf

[2] PwC Indonesia, Power in Indonesia, November, 191, 2017. https://www.pwc.com/id/en/energy-utilitiesmining/assets/power/power-guide-2017.pdf

[3] Energy education, Retrieved from Energy Education, University of Calgary, 2020 . https://energyeducation.ca/encyclopedia/Power_plant

[4] GE Jenbacher, Technical Description Genset JGS 620 GS-N.L, 2013.

[5] R. Chalmeta, S. Palomero, and M. Matilla, "Methodology to develop a performance measurement system in small and medium-sized enterprises," International Journal of Computer Integrated Manufacturing, $25 \quad(8), \quad$ pp. 716-740, 2012. https://doi.org/10.1080/0951192X.2012.665178

[6] S. V. Oprea and A. Bâra, Key Technical Performance Indicators for Power Plants. Recent Improvements of Power Plants Management and Technology, 2017. https://doi.org/10.5772/67858

[7] P. Tallapragada, M. Shkaratan, A. K. Izaguirre, J. Helleranta, S Rahman, and S. Bergman, Monitoring Performance of Electric Utilities: Indicators and Benchmarking in Sub-Saharan Africa, The World Bank, 2009.

[8] Y. Gunawan, C. L. F. Simorangkir, and M. Aman, "Analisis kinerja PLTU Indramayu sepanjang tahun 2015", Ketenagalistrikan Dan Energi Terbarukan, 16 (2), pp. 97-106, 2017.

[9] T. L. Saaty, What is the Analytic Hierarchy Process? NATO ASI Series, Vol. F48. Mathematical Models for Decision Support. Edited by G. Mitra. Springer Verlag Berlin Heidelberg, 1988.

[10] R. W. Saaty, R. W., "The analytic hierarchy process-what it is and how it is used," Mathematical Modelling, 9 (3-5), pp. 161-176, 1987. https://doi.org/10.1016/0270-0255(87)90473-8.

[11] T. L. Saaty and K. P. Kearns, The Analytic Hierarchy Process. Analytical Planning, pp. 19-62, 1985 https://doi.org/10.1016/b9780-08-032599-6.50008-8

[12] H. Proces, "Using the analytic hierarchy process in evaluating decision alternatives," Operations Research and Decisions, 20 (1), pp. 5-23, 2010

[13] J. Barzilai and F. A. Lootsma, "Power relations and group aggregation in the multiplicative AHP and SMART," Journal of Multi-Criteria Decision Analysis, 6 (3), pp. 155-165, 1997. https://doi.org/10.1002/(SICI)1099-1360(199705) 